\title{
PENGARUH MINUMAN ISOTONIK ISOPLUS TERHADAP KELARUTAN KADAR KALSIUM GIGI (SECARA IN VITRO)
}

\author{
Nurwiyana Abdullah
}

\begin{abstract}
ABSTRAK
Gigi dan mulut merupakan salah satu organ penting dalam tubuh kita, Gigi tersusun atas mahkota dan akar gigi. pada penampang melintang email gigi merupakan suatu jaringan yang mengalami proses mineralisasi yang sangat tinggi dan rentan terhadap serangan asam, karena minuman isotonik merupakan salah satu dari beberapa produk minuman ringan karbonasi atau non karbonasi untuk meningkatkan kebugaran, yang mengandung gula, asam sitrat, dan mineral. Pada penelitian laboratorium menunjukkan bahwa keasaman minuman bersoda yang merupakan minuman yang paling banyak digunakan oleh masyarakat terutama atlit atau olahraga, dan jus buah dapat menyebabkan pengikisan permukaan email gigi. menunjukkan bahwa minuman dengan $\mathrm{pH}$ 5,5 atau kurang cenderung mengikis permukaan email, sehingga dapat menyebabkan sensitifitas padapermukaan gigi. Berdasarkan penelitian dari Director of Biomaterials Science, Maryland University of Baltimore Dental School, membuktikan bahwa minuman isotonik dan minuman energi bersifat lebih erosif daripada minuman soda karena pengaruh asam di dalam minuman tersebut. Bahan dan metode: Jenis penelitian ini adalah eksperimen laboratorium dengan desain time seriest jumlah sampel yang digunakan dalam penelitian ini sebanyak satu gigi premolar post ekstraksi kurang dari satu minggu. Berdasarkan hasil penelitian dapat disimpulkan bahwa kadar kalsium gigi yang larut pada minuman isotonik adalah sebesar 12, 68 ppm.
\end{abstract}

Kata Kunci : minuman isotonik, kadar kalsium

\section{PENDAHULUAN}

Kesehatan gigi amat signifikan untuk diperhatikan karena gigi dan mulut merupakan bagian tubuh yang penting kegunaannya terutama untuk mengunyah makanan. Sehingga apabila kondisi gigi dan mulut tidak sehat, pasti akan banyak sekali menimbulkan masalah yang dapat diderita oleh seseorang karena kondisi kesehatan giginya. Dengan kondisi yang tidak sehat atau kurang sehat sehingga kemungkinan yang sangat berpeengaruh adalah dapat menimbulkan terjadinya karies gigi yang sulit dihindari karena factor makanan dan minuman yang tidak atau kurang diperhatikan. karies merupakan suatu proses demineralisasi yang progressif, menyebabkan desintegrasi komponenkomponen mineral yang berakibat terbentuknya kavitas (lubang).
Negara-negara di dunia karies merupakan masalah utama hampir sekitar 60 - 90\% mulai dari anak-anak, remaja, dewasa dan orang lanjut usia, Menurut Riskesda 2018 Prevalensi karies di Indonesia memcapai 89,9\% untuk seluruh kelompok berdasarkan karakteristik. Pengalaman karies terutamaa untuk Sulawesi Selatan masih cukup tinggi $85 \%$, maka masih perlu adanya untuk perubahan pengetahuan, perilaku dan tinadakan yang mengarah ke perbaikan aatau penurunan angka karies gigi.

Salah satu faktor yang dapat mempengaruhi terjadinya demineralisasi email gigi adalah minuman yang sering dikomsumsi oleh oleh para atlet dan anak remaja, minuman ini adalah minuman isotonik isoplus, Hasil penelitian laboratorium menunjukkan bahwa keasaman minuman 
bersoda, minuman olahraga, dan jus buah dapat menyebabkan pengikisan permukaan email gigi. Penelitian telah menunjukkan bahwa minuman dengan $\mathrm{pH}$ 5,5 atau kurang cenderung mengikis permukaan email. Contoh minuman yang memiliki potensi menyebabkan peningkatan erosi gigi yaitu minuman berkarbonasi, minuman olahraga, minuman jeruk, dan jus buah. Minuman ringan berkarbonasi memiliki $\mathrm{pH}$ mulai 2,33,4 , sedangkan jus buah dan minuman beralkohol masing masing memiliki $\mathrm{pH}$ berkisar 2,1-3,6 dan 2,8-3,9. (Zahara, 2012)

Secara in vitro telah terbukti bahwa secara kimiawi kerusakan akibat asam pada permukaan gigi dapat menyebabkan erosi gigi. Ion asam dapat berpenetrasi ke dalam prisma yang terdapat pada email sehingga menjadi porus. Kondisi ini dikenal sebagai permulaan demineralisasi pada permukaan bagian dalam email gigi. (Panigoro, 2015)

Berdasarkan hasil survei tentang keadaan klinis erosi gigi dilaporkan di United Kingdom lebih dari $17 \%$ remaja menunjukkan erosi gigi yang parah. Masalah yang paling parah terjadi pada atlet olahraga, investigasi dari Amerika Serikat melaporkan bahwa lebih dari 35\% atlet memiliki erosi gigi. Prevalensi serupa terjadi di Australia, melaporkan studi antara 20-30\% dari atlet disurvei memiliki erosi gigi. (Seow WK, 2005)

Berdasarkan penelitian dari Director of Biomaterials Science, Maryland University of Baltimore Dental School, membuktikan bahwa minuman isotonik dan minuman energi bersifat lebih erosif daripada minuman soda karena pengaruh asam di dalam minuman tersebut. Kebanyakan minuman ringan, termasuk minuman isotonik mengandung beberapa jenis asam, seperti phosphoric acid, asam sitrat, malic acid dan tartaric acid. (Panigoro, 2015)

Makanan dan minuman seseorang sangat mempengaruhi proses remineralisasi dan demineralisasi email berlangsung terus menerus di dalam rongga mulut, jika pHdi baawah 5,5 selama lebihdari 30 - 60menit akan mengakibatkan demineralisasi berkembang sehingga terjadi kerusakan pada struktur gigi, saat ini banyak minuman ringan dengan $\mathrm{pH}$ di bawah 5,5 yang dikonsumsi oleh masyarakat sehingga proses remineralisaasi akan membentuk pori-pori kecil atau porositas pada permukaan email sehingga menyebabkan larutnya mineral kalsium.

Berdasarkan uraian dan data di atas, dapat diketahui bahwa minuman Isotonik bersifat asam yang dapat melarutkan kalsium pada gigi, sehingga peneliti ingin mengetahui berapa kadar kalsium pada gigi yang terlarut pada perendaman minuman Isotonik tersebut.

\section{METODE PENELITIAN}

Jenis penelitian yang digunakan adalah penelitian eksperimen laboratorium dengan desain penelitian time series design (rancangan rangkaian waktu) Dengan Prosedur Kerja sebagi berikut :

1. Penyediaan gigi premolar berdasarkan kriteria

a. Post Ekstraksi perawatan Orthodontik

b. Post Ekstraksi karena alasan penyakit periodontal

c. post Ekstraksi kurang dari 1 minggu

d. Gigi Premolar Permanen

2. Pembilasan dan pengeringan gigi premolar yang telah dicabut

3. Penyediaan minuman isotonic Isoplus yang akan digunakan sebagai media untuk penelitiaan 
4. Pengukuran PH pada Minuman Isotonik Isoplus

5. Perendaman mahkota gigi pada Minuman Isotonik Isoplus di dalam gelas ukur dengan volume $10 \mathrm{ml}$ selama 15,30 , 45, dan 60 menit

6. Setelah itu pindahkan minuman Isotonik Isoplus yang sudah direndam ke dalam tabung reaksi dan masing - masing berikan label sesuai dengan waktu perendaman

7. Pengukuran kadar Kalsium pada minuman isotonic Isoplus setelah perendaman 15, 30, 45 dan 60 menit dengan menggunakan alat SSA (Spektrofotometri Serapan Atom)

\section{HASIL DAN PEMBAHASAN}

Penelitian ini dilakukan di Balai Besar Laboratorim Kesehatan (BBLK) Makassar Sulawesi Selatan. Di BBLK digunakan Sprektrofotometer untuk memeriksa kelarutan kalsium setelah perendaman gigi post ekstraksi dalam minuman isotonic Isoplus. Penelitian ini bertujuan untuk mengetahui besar kelarutan kalsium pada gigi yang terlarut pada perendaman minuman Isotonik Isoplus (secara invitro). Sampel penelitian meliputi 1 gigi Premolar yang di rendam pada minuman isotonik Isoplus dalam rangkaian waktu 15, 30, 45 dan 60 menit.

Komposisi dari minuman isotonik Isoplus yang digunakan dalam penelitian ini, yaitu: Air, gula, pengatur keasaman (asam sitrat, trinatrium sitrat), natrium klorida, antioksidan vitamin C, kalium klorida, kalsium laktat, perisa sintetik grape fruit, dan magnesium laktat. Sebelum dilakukan penelitian di laboratorium, terlebih dahulu minuman diukur pH-nya. Adapun hasil pengukuran $\mathrm{pH}$ kedua minuman tersebut dengan menggunakan $\mathrm{pH}$ meter dan $\mathrm{pH}$ indikator ada pada tabel 1.

Tabel 1 Distribusi pH Minuman Isotonik Isoplus

\begin{tabular}{|l|c|c|}
\hline \multirow{2}{*}{$\begin{array}{l}\text { Jenis } \\
\text { Minuman }\end{array}$} & \multicolumn{2}{|c|}{$\mathbf{p H}$} \\
\cline { 2 - 3 } & $\begin{array}{c}\text { Menggunakan pH } \\
\text { meter }\end{array}$ & $\begin{array}{c}\text { Menggunakan pH } \\
\text { Indikator }\end{array}$ \\
\hline $\begin{array}{l}\text { Minuman } \\
\text { Isotonik } \\
\text { (ISOPLUS) }\end{array}$ & 3.4 & 3 \\
\hline
\end{tabular}

$\mathrm{pH}$ meter dan $\mathrm{pH}$ indikator adalah alat ukur yang digunakan dalam melihat derajat keasaaman dan kebasaan yang ada dalam benda cair. Dilihat dari tabel di atas $\mathrm{pH}$ pada minuman isotonk Isoplus $<7,0$ yaitu $=3,4$, yang berarti minuman tersebut bersifat Asam.
Setelah itu dilakukan perendaman gigi ke dalam $10 \mathrm{ml}$ minuman isotonik Isoplus dengan rangkaian waktu 15, 30, 45, dan 60 menit dan di ukur kadar kalsium pada minuman isotonik yang telah direndam gigi menggunakan SSA (Spektrofotometri Serapan Atom), yang dapat dilihat pada tabel berikut: 
Tabel 2 Hasil Pengukuran Kadar Kalsium Dalam Satuan Part Per Million (PPM)

\begin{tabular}{|c|c|c|c|}
\hline \multirow{2}{*}{ No. } & \multirow{2}{*}{ Kode Sampel } & \multirow{2}{*}{ Satuan } & Hasil Pengujian \\
\cline { 3 - 4 } & & & Kalsium (Ca) \\
\hline 1 & Kontrol & Ppm & 33,79 \\
\hline 2 & 15 menit & Ppm & 35,78 \\
\hline 3 & 30 menit & Ppm & 42,84 \\
\hline 4 & 45 menit & Ppm & 45,39 \\
\hline 5 & 60 menit & Ppm & 46,47 \\
\hline
\end{tabular}

Untuk mengetahui kadar kalsium gigi yang terlarut, dapat diketahui dengan cara menghitung selisih kadar Kalsium setelah perendaman dengan kadar kalsium pada minuman Isotonik (kontrol) dengan menggunakan persamaan sebagai berikut :

Keterangan: $\mathbf{P p m}=\mathbf{p p m}_{\mathbf{1}}$ - $\mathbf{p p m _ { \mathbf { o } }}$
- Ppm : Kadar Kalsium gigi yang terlarut - $\mathrm{ppm}_{1}$ : Kadar kalsium setelah perendaman 15, 30, 45, dan 60 menit

- ppmo: Kadar kalsium minuman isotonik (kontrol)

Dari perhitungan persamaan di atas, didapatkan hasil sebagai berikut:

Tabel 3 Distribusi Hasil Kadar Kalsium Gigi pada Minuman Isotonik

\begin{tabular}{|c|c|c|}
\hline \multirow{2}{*}{ Jenis Larutan } & Waktu (menit) & Kadar Kalsium gigi (ppm) \\
\hline \multirow{2}{*}{$\begin{array}{c}\text { Minuman Isotonik } \\
\text { (ISOPLUS) }\end{array}$} & 15 & 1.99 \\
\cline { 2 - 3 } & 30 & 9.05 \\
\cline { 2 - 3 } & 45 & 11.60 \\
\hline
\end{tabular}

Dari tabel di atas dapat diketahui Kadar kalsium gigi pada perndaman minuman isotonik berbeda di setiap waktu penelitian. Pada menit ke - 15 terdapat kalsium pada gigi yang larut sebesar 1,99 ppm dan terus menerus mengalami kelarutan hingga menit ke 60 sebesar 12,68 ppm.

Penelitian ini menggunakan minuman kemasan yang diperjual belikan di pasar, dan gigi post ekstraksi. Sedangkan pengukuran kelarutan kalsium dilakukan di Balai Besar Laboratorium Kesehatan (BBLK) Makassar, Sulawesi Selatan.

Jenis penelitian yang digunakan adalah eksperimen laboratorium. Penelitian ini menggunakan desain penelitian time series. Penelitian dimulai dengan pembersihan gigi, setelah itu bagian mahkota gigi dimasukkan ke dalam minuman isotonik. Penelitian ini meneliti kadar kalsium gigi karena kalsium adalah unsur pertama yang paling banyak terdapat dalam email gigi. Terurainya ion kalsim memberikan efek negatif pada email gigi, dimulai dari demineralisasi email, berkurangnya ketahanan email, hingga terjadi erosi.

Lama waktu perendaman gigi dalam penelitian kali ini adalah 15, 30, 45, dan 60 menit. Hal tersebut didasarkan pada, 1 menit adalah estimasi jumlah lama waktu terpaparnya email gigi dengan minuman yang dikonsumsi dalam setiap gelas/hari. Jadi interpretasi waktu dalam penelitian ini dapat menggambarkan konsumsi minuman dalam 15, 30, 45, dan 60 hari (2 bulan). Dari hasil penelitian yang telah dilakukan, dapat diketahui bahwa minuman isotonik menunjukkan kelarutan kalsium yang 
merupakan awal demineralisasi email gigi. Salah satu tanda demineralisasi email ialah larutnya berbagai mineral, utamanya kalsium.

Berdasarkan hasil penelitian yang dilakukan, diketahui bahwa minuman isotonik mempunyai pengaruh terhadap kelarutan kalsium dalam kristal hidroksiapatit yang merupakan awal demineralisasi email, Hasil pengukuran $\mathrm{pH}$ minuman pada tabel 1 memperlihatkan bahwa minuman isotonik memiliki $\mathrm{pH}$ yang rendah yaitu 3,4 dengan pengukuran menggunakan $\mathrm{pH}$ meter. Adapun hasil kadar kalsium gigi yang larut pada perendaman minuman Isotonik pada tabel 3 memperlihatkan pada menit ke-60 adalah sebesar 12,68 ppm.

Hasil tersebut sejalan dengan pernyataan Prasetyo yang menyatakan makanan dan minuman asam yang memiliki $\mathrm{pH}$ di bawah 7 , salah satunya minuman yang mengandung asam dapat menyebabkan email gigi terkikis. Pada menit ke 60 adalah titik maksimal kelarutan kalsium dalam minuman isotonik.

Hal yang sama juga diungkapkan oleh Mettler yang mengatakan bahwa minuman isotonik dapat mengikis gigi sehingga hal ini dapat menyababkan terjadinya demineralisasi email gigi. Beberapa penelitian membuktikan bahwa minuman isotonik (sports drinks) biasanya diminum secara perlahan, sehingga sisa-sisa residu minuman ini dapat tertinggal dalam rongga mulut untuk beberapa menit. Hal ini dapat mempengaruhi kesehatan gigi, karena minuman seperti minuman isotonik (sports drinks) mempunyai $\mathrm{pH}$ yang rendah yaitu dibawah $\mathrm{pH}$ kritis sehingga dapat menyebabkan erosi gigi.
Sejalan dengan pendapat Wolff dan Mettler, Anthony juga mengatakan bahwa bahwa minuman isotonik (sports drink) dan minuman energi bersifat erosif karena pengaruh asam di dalam minuman tersebut. Tabel 2 juga memperlihatkan bahwa nilai kelarutan kalsium dalam minuman isotonik. Dan dari hasil pengukuran $\mathrm{pH}$ minuman pada tabel 1 memperlihatkan bahwa minuman isotonik bersifat asam. Minuman ringan yang dapat mengikis permukaan email adalah minuman yang sangat asam sehingga minuman ini tidak mudah dihilangkan oleh saliva. Hal ini disebabkan oleh beberapa faktor yang memengaruhi proses demineralisasi, yaitu jenis dan konsentrasi asam minuman, dan derajat keasaman $(\mathrm{pH})$.

Hal ini sejalan dengan pernyataan Prasetyo yang menyatakan bahwa faktor yang mempengaruhi proses demineralisasi, tidak hanya ada pada jenis dan konsentrasi asam minuman, Pada penelitian ini durasi waktu atau lamanya gigi berkontak dengan asam juga memengaruhi proses demineralisasi, nilai kelarutan kalsium mengalami kenaikan terus menerus hingga menit ke-60. Hal ini berarti bahwa jumlah kadar kalsium gigi yang terlarut tidak hanya dipengaruhi oleh derajat keasaman $(\mathrm{pH})$, tetapi durasi waktu atau lamanya asam berkontak dengan gigi juga dapat memengaruhi kadar melarutnya kalsium, sehingga terjadi kelarutan kalsium gigi. Selain itu, kandungan asam yang merupakan komponen yang bersifat erosif pada minuman dapat merusak email. Aplikasi asam lemah yang berulang-ulang dan teratur pada permukaan gigi juga dapat menghilangkan mineral yang terdapat pada daerah itu. Demineralisasi email adalah 
rusaknya hidroksiapatit gigi yang merupakan komponen utama email akibat proses kimia. Kondisi demineralisasi email terjadi bila $\mathrm{pH}$ larutan di sekeliling permukaan email lebih rendah dari 5,5, (umumnya $\mathrm{pH}$ minuman ringan berkisar 2,3-3,6).

Penelitian terdahulu yang pernah dilakukan oleh Mettler mengatakan bahwa minuman isotonik dapat mengikis gigi sehingga hal ini dapat menyebabkan terjadinya demineralisasi email gigi. Hal ini dapat memengaruhi kesehatan gigi, karena minuman seperti minuman isotonik mempunyai $\mathrm{pH}$ yang rendah yaitu di bawah $\mathrm{pH}$ kritis sehingga dapat menyebabkan erosi gigi. Penurunan kekerasan permukaan email gigi yang besar akibat perendaman dalam minuman isotonik sesuai dengan penelitian terdahulu, mengatakan bahwa bila terjadi penurunan satu satuan $\mathrm{pH}$, akan dapat menyebabkan laju pelepasan kalsium sebesar 19,5 kali, ini berarti semakin kecil $\mathrm{pH}$ atau semakin asam media, maka semakin tinggi laju reaksi pelepasan kalsium dari email

\section{KESIMPULAN DAN SARAN}

Berdasarkan hasil penelitian mengenai kadar kalsium gigi yang terlarut pada perendaman minuman isotonik secara invitro dapat disimpulkan bahwa:

1. Minuman Isotonik memilki $\mathrm{pH}$ rendah yaitu 3,4 yang berarti berisfat asam

2. Perendaman gigi dalam minuman isotonik menunjukkan nilai kadar kaslium gigi yang berbeda satiap waktu perendaman. kadar kalsium gigi dalam perendaman minuman isotonik mulai larut pada menit ke 15 sebanyak 1.99 ppm, pada menit 30 sebanyak 9.05 ppm, pada menit 45 sebanyak 11.60 ppm, pada menit 60 sebanyak 12.68 ppm.

Berdasarkan hasil yang diperoleh pada penelitian ini, maka dapat disarankan bahwa, minuman isotonik Isoplus memiliki dampak buruk bagi kesehatan gigi, jika dikonsumsi lebih lama akan manyebabkan demineralisasi pada gigi. Jadi sebaiknya dikurangi dalam mengkonsumsi minuman tersebut.

\section{DAFTAR PUSTAKA}

Zahara MA, Tee ML, Hazirah M, Selvamary $\mathrm{S}$, Phor YJ, Hasnani NI, et al. Relationship between Food Habits and Tooth Erosion Occurrence in Malaysian University Student. Malaysia Journal Medical Sciences; 2012:19(2):56-66.

Panigoro, Syahril, Damajanty H.C. Pangemanan, Juliatri. 2015. Kadar Kalsium Gigi yang Terlart pada perendaman Minuman Isotonik. $e-$ Gigi(Eg). 3:356 -360.

Seow WK, Thong KM. Erosive Effects of Common Beverages on Extracted Premolar Teeth. Australian Dental Journal; 2005:50(3):173-8.

Arisworo, Djoko dkk. 2006. IImu Pengetahuan Alam (Fisika, Biologi, Kimia): Grafindo Media Pratama.

Dharmawati, Ayu.Konsumsi Soft Drink menyebabkan kerusakan gigi. Jurnal IImu Gizi Volume 6 Nomor 1 Februari 2015: 43 - 50 https://usaha321.net/pengertianph.html. Diakses pada hari selasa tamggal 23 April 2019 pukul 21.04

llyas, Muhammad. 2012. Kelarutan Magnesium email pada perendaman gigi dalam minuman yang mengandung asam bikarbonat dan asam sitrat (iinvitro).

Ireland, Robert. 2014. Kamus Kedokteran Gigi. Jakarta:EGC

Kasuma, Nila, M. Biomed. 2015. Fisiologi dan Patologi Saliva. Padang: Andalas University Press.

Kidd, Edwina A.M., Sally Joyston - Bechal. 1991. Dasar - dasar Karies Penyakit dan Penanggulangannya. Jakarta:EGC

Koswara S. Minuman Isotonik. [serial online] Available from: http://www.tekpan.unimus.ac.id/wp 
content/uploads/2013/07/minuman isotonik.pdf; 2009.

Musdalifah, Sitti. 2016. Dekolagenasi Limbah Tulang Paha Ayam Broiler (Gallus domesticus) oleh Natrium Hidroksida ( $\mathrm{NaOH})$ untuk Penentuan Kadar Kalsium (Ca) dan Fosfat (PO4).

Nasution, Abdillah Imron. 2016. Jaringan Keras Gigi Aspek Mikrostruktur dan aplikasi riset. Banda Aceh: Syiah Kuala University Press.
Pradini, Lusiana Ayu. 2016. Pengaruh larutan jeruk nipis dan gula pada dosis yang berbeda sebagai larutan penyemprot terhadap lama tetas dan saleable dod itik Tegal

Prasetyo EA. Keasaman minuman ringan menurunkan kekerasan permukaan gigi. Dental Journal;2005:38(2):603.

Ramadhani, Syarifah Fitria. 2013. Kelarutan Fosfat Email pada Perendaman Gigi dalam minuman Isotonik dan Asam Folat. 